\title{
PROGRAM OF STATE SUPPORT TO AGRICULTURAL CREDITING
}

\author{
Željko Vojinovićl, Vera Zelenović2 ${ }^{2}$ Drago Cvijanovic ${ }^{3}$
}

\begin{abstract}
One of the most important industries in Serbia are agriculture, the potential for the State, which is on its way to become a member of the European Union, represents the backbone of economic growth and development. Integrating with the EU represents a task to establish such a model and framework of relations of the State towards agriculture in order to easier harmonization of national policies with the policy of the EU. In this day and age when growing awareness about the importance of nutrition and the importance of the arable land, it is necessary to devote special attention to the problem of the lack of funds in the framework of agricultural production. A solution to the problem of technical and technological processes in the manufacture of food products, especially healthy food, you can browse in the measures of improving and increasing production through different approaches to stimulate and subsidizing of agricultural producers. It is certainly in the interest of the State, so it is for that reason necessary to devote special attention to budget and how financing and other measures in the direction of the stimulus of all participants in the market who participate in agricultural production.
\end{abstract}

Key words: agricultural production, a policy of financing, crediting, development, harmonisation.

JEL: Q18, Q28, Q48

\section{Introduction}

Approaching to EU means also the adjustment to legal, organisational, systematic and other norms within agriculture. All these changes in the Republic of Serbia occur for many years back in terms of an owner change, privatisation and sale of land, increasing demand, which

1 ŽeljkoVojinović Ph.D., Assistant Professor, University Novi Sad, Economic faculty Subotica, Segedinski put no. 9-11, Subotica, Serbia, Phone +381 24628 030, E-mail: zeljko.vojinovic@ef.uns.ac.rs,

2 Vera Zelenović Ph.D., Professor, University Novi Sad, Economic faculty Subotica, Segedinski put no. 9-11, Subotica, Serbia, Phone +381 24628 164, E-mail:vera.zelenovic@ef.uns.ac.rs.

3 Drago Cvijanović, Ph.D., Full Professor University in Kragujevac, Faculty of Hotel Management and Tourism, Vrnjačka Banja, Republic of Serbia, Vojvodjanska street no 5A, 36210 VrnjačkaBanja, Serbia, Phone +381 63295 111, E - mail:dvcmmv@gmail.com

EP 2017 (64) 1 (339-358) 
has as a result the increase in prices of arable land, enlargement of agricultural holdings related to purchasing larger areas of land by a small number of buyers, etc. These processes and changes are still ongoing and doing business of farmers is increasingly based on the market principles.

The state can realise a set of objectives of the agrarian policy by different instruments. The instruments of economic, technical and legal character are primarily available. If it is about the economic instruments, first of all, these are taxes and other budgetary financing, investments in agriculture, the price policy, where surely can be mentioned the protection of domestic manufacturers in regard to foreign competition. The protection of crops and fruits against the different risks of destruction, through stimulating the insurance companies in direction of taking the risk, is an important economic instrument. Technical nature instruments, such as the introduction of new and modern machinery, recent technological solutions of chemical processes, consolidation of holding, reallocation of holding and others, are correlated to the previously mentioned instruments of economic character, while their implementation is easier if implement jointly. Legal instruments help regarding easier organization and doing business to farmers, in turnover of property and land, realisation of their creditors' rights, etc. Legal aspect has its special severenessin the sector of agro-food production. Increasing attention which pays to food safety issues imposes more harsh business conditions for food manufacturers and tradesmen. It results by an increasing number of legal decisions in force, as well as their constant modifications. Hence a large number of legal decisions of the EU, which refer to the field of agriculture and food safety - over $40 \%$ of total number of legal decisions within the EU, are in force (Bogdanov, 2007).

All mentioned instruments, if apply jointly and synchronized, provide a far greater effect than individual and partly renamed policies. The goal of this manuscript is to perceive the significance and thereby also the potential of agricultural production in the state, but those goals are very hard to achieve without an adequate state agrarian policy. Analysing different experiences of developed and successful countries in the field of agriculture, there can conclude that there is no successful agriculture without the state intervention in this sector. However, the state influence has completely different forms in some countries. For example, the Netherlands, one of the leading world exporters (second-ranked country in the world by the value of agricultural export, of 72 milliard euro in the year 2011) bases its agriculture motivation on the EU Common Agricultural Policy, with a generous budget meant for subsidizing agriculture. On the other hand, Brazil is at the top of the world agricultural exporters, and most of its agrarian budget Brazil directs to research and development in the field of agriculture, and not the subsidies of production. These examples clearly point out to inability of agro-food sector development without the state support, whatever the concept of liberal economy would be fruitful (Bogdanov, 2007).

\section{Methodology}

The subject of this manuscript is exactly to review the situation in agricultural production, possibilities and capacities of a branch, and first of all, the state impact to a financial sector in terms of crediting, as well as the policy of farmers stimulations by the state. 
Serbian agriculture could face very difficult challenges on its way to the European integrations, but this sector will have, at the same time, also many benefits from the European Union membership; if Serbia is a member of the European Union, it would get around 1.6 milliards euros per year from the agricultural and rural developmental funds, which amounted 55 milliard euros in 2010.Serbia, on its way to the EU membership will have to adjust to regulations and standards of EU, which will significantly change the situation in Serbian agriculture. Economic goals, targeted by the Copenhagen criteria (which define conditions for accession of any country to the European Union) imply making and functioning of market economy which would be capable to integrate in the market economies of other memberstates, capability to withstand competition, in a way that the state economy withstands the entry onto the unitary EU market and the adjustment of an entire set of the European Union rules and practice by which it works, known as acquiscommunautaire(http://euinfo.rs/files/ Publikacije-srp/31_Poljopricreda_i_EU.pdf).

\section{The state of agricultural production in Serbia and the current support of EU}

According to Stanković (2012), the agrarian policy in its broader sense, can be defined as a program of directing agricultural development within already chosen model of development as a whole. The subject of the agrarian policy is the entire vertical of agro-industrial production, which comprises:

- Production of agrarian inputs,

- Production of the primary agricultural products,

- Production of agro-food products,

- Including turnover,

- Final consumption and the policy of population nutrition.

The Republic of Serbia is located on area of totally 8,840,000 ha. Agricultural area covers $5,346,597 \mathrm{ha}$, or $60 \%$, of which utilised agricultural area is 3,437,423 ha, and arable land is 2,513,154 ha. Difference between the utilised and arable land is mostly meadows and pastures (Birovljev, Vojinović, Balaban, 2015). It is important to point outtoa size of plots and a number of holdings,from the aspect of agricultural production and economic business indicators. Dissection of agricultural land implies the fragmentized production with increased transport costs. There are 631,122 registered agricultural holdings in Serbia, of which 628,555 family holdings and 2,567 legal entities. It is considered to be around 450,000 registered holdings.

Recognizing the socio-economic structure of holdings, according to their members' income sources, point out to a fact that 326,015 family holdings in Serbia (52\% of a total number) don't have other incomes except agriculture. Besides, it provides livelihood income to persons employed in the production-sale processes, which don't occur exclusively in the field of agriculture, but in the purpose of its support (production of artificial fertilizers, agricultural machinery, packaging and transport equipment for agricultural products). It is expected of 
agriculture to be a driving engine of rural areas development and thereby affects the decrease of growing regional disparities (Bogdanov, Babović, 2014).

According to Birovljev and associates (2015), the most of arable land is in Vojvodina 1,589,065 ha, of which in South Banat 315,247 ha. It amounts 5.3 ha per holding, while the Czech Republic has an average size of holding 152.4 ha, and Malta only 0.9 ha. The average in Serbia per capita is 0.5 ha, in Banat 1.23 ha.

According to the same authors, the value of total production is 3.3 milliard euros, which is far away from the potential production. From an insurance underwriter's point of view, a premium that can be realised in arable land could increase up to 10 times from the current value.

Agriculture plays an important role in economic and social life of Serbia. According to data of the Ministry of Agriculture, more than two million people or 700,000 families are engaged in this activity. One European Commission's report stated that around 55\% of population in Serbia lived in rural areas, while one third of active Serbian population depended completely or partly on the agricultural production as a food source (http://euinfo.rs/files/Publikacijesrp/31_Poljopricreda_i_EU.pdf).

It is almost impossible to state everything that affects production, but we will try to mention some of more important factors (Brkanić,1996): lack or excess moisture in soil and air (drought or excessive rain), too low or too high temperature of soil and air (frost or heat stroke), lack or excess of plant nutrients, hail, storm wind, flood, fire, plant diseases (fungi, bacteria, viruses), pests (insects, rodents), weeds (Maliva, Missimer, 2012).

The state has introduced incentives to these indicators of agricultural production in terms of subsidizing the insurance premiums, but only for legal entities and registered holdings, which have been engaged in this activity. Since the year 2007, there has been introduced the subsidy of $30 \%$ of premium, while in 2009 this percentage was increased to $40 \%$. Approximately the same amounts of subsidies can be found in other European countries to which we compared, while in half of these countries this form of state support hasn't even been introduced (Tsakiris, Vangelis, 2005).

Additional abilities of subsidizing were left to policies, implemented by the local authorities. Significance of agricultural production, especially for Serbia, in this manuscript we state primarily for the following reasons:

$\checkmark \quad$ Strategic economic branch of the state,

$\checkmark \quad$ Substantially dependable on natural conditions,

$\checkmark \quad$ Great but unused potential,

$\checkmark \quad$ Significant market participant,

$\checkmark \quad$ Great impact on human health and environment. 
The necessity of state intervention in agriculture results from this production peculiarity, i.e. slow capital turnover, which was invested in agricultural production, due to a seasonal character of this production. Climate factor in agricultural production plays an increasing role, because it is about the organic production which realise in open air (Birovljev, Glamočanin, 2011).

The necessity of interventions in the sector of agriculture starts from a fact that the agrarian sector has been constituted by a large number of small family firms, as very important in the developmental system functioning of each country. Agrarian interventionism is an issue around which have always led a controversial debate. Lately are present the price policy and the support to farmers income. During the second half of XX Century, the agrarian policy has continuously pushed the agrarian sector of developed countries in overproduction, causing the decrease in prices of basic agricultural products on the world market. Such policy has led to disturbance of balance between two organisation models of agro-sector, agro-business and family agriculture, by accelerating the structural reforms (Birovljev, Tomić, 1996).

Observing the treatment of agrarian interventionism, we can conclude that a general consensus was reached on unreasonably high costs in managing the modern agrarian policy, as well as distorting effects produced on the world market of agricultural products by a model of state interventions in the agrarian sector. It doesn't mean simultaneously that agrarian economists will abandon the idea that the agrarian sector should be „protected“. Hence, the current debate regarding the agrarian interventionism is mainly oriented towards the identification of the legitimate right of the state to intervene and what is the cost of this intervention. In that sense, the basic reasons for the state intervention in the agrarian sector were identified in next strategic fields (Zakić, Stojanović, 2008):

$\checkmark$ Increase of agricultural production efficiency,

$\checkmark$ Protection of farmers' income,

$\checkmark$ National food safety,

$\checkmark$ External effects and public goods in agriculture.

When Serbia joins the European Union, agricultural areas in the European Union will increase for 5,097 million hectares, i.e. 3\% of agricultural areas used in EU. Until Serbia joins the European Union, it has to adjust the subsidy policy to the European practice. Export of agricultural products increases from year to year and makes almost one fourth. Agriculture and rural development represent one of the most demanding sectors in the process of harmonization with the European Union standards. Regulations in the field of agriculture make almost one third of all EU regulations (http://euinfo.rs/files/Publikacijesrp/31_Poljopricreda_i_EU.pdf).

The European Union has also financed the purchase of laboratories and other equipment to monitor and combat rabies and classical swine fever (additional 3.5 million euros), as well as the technical support for repression of these two animal diseases (two million euros). This will help collecting data in the field, aiming to establish the rabies and classical swine 
fever diagnosis. This project will help the improvement of population health and open up opportunities for expanding the Serbian market and food export into the European Union in future (http://euinfo.rs/files/Publikacije-srp/31_Poljopricreda_i_EU.pdf).

\section{Agrarian policy of the European Union}

Functioning of the European Union, i.e. its common policies, bases on the European Parliament, Council, European Commission, Court of Justice and Court of Auditors. These five institutions represent the national framework underlying the European Union, and by their interaction provide freely functioning of the European Union. Special attention in this complex system is paid to the creation and adoption of a budget. The initial budget creates by the Commission and sends to the Council for review. The Council rejects or adopts the suggested budget by the qualified majority and sends it to the Parliament (Bureau, Mahe, 2008).

The significance of the common agricultural policy and rural development grows from year to year. This growth increases together with the European Union enlargement. It is inevitable to mention that the common agrarian policy is the oldest and, until now, the most carefully reformed sector common policy and represents the most demanding segment of economic activities in the European Union.

The initial principles, that common agricultural policy is defined on, are as follows:

- Unique market,

- Union priority,

- Financial solidarity.

The unique market implies a free circulation within the European Union, without any customs duties, while it implies the unique tariff protection for products outside the European Union (http://euinfo.rs/files/Publikacije-srp/31_Poljopricreda_i_EU.pdf). The obligation of financing agriculture imposes to all EU members through financial solidarity.

In the history of the common agricultural policy of the European Union may differ the following periods (Mihailović, Cvijanović, Hamović, 2009):

1. Idea and formation of policy in the period from 1946 until the beginning of " 60 ies,

2. Application of strong financial support to agriculture from ' 60 ies to the end of ' 80 ies,

3. The beginning of ' 90 ies and so called MacSherry reform in 1992, with turning point in decreasing the budget support,

4. Period after the year 2000 and strengthening of rural development followed by the programs for environmental protection.

According to Bureau and Mahe (2008), the common agricultural policy is the most expensive policy from the aspect of the European Union central budget. For many years, its share in the total, central budget was amounted more than half of totally available assets. This fact, 
which puts agriculture at the top of the European priority list, is often wrongly interpreted in domestic public. Countless times before was heard requirements for increasing the budget financing meant for the Serbian agriculture. As a base for increasing often uses looking up to the European Union, but an avoidable comment is that EU allocate a half of its budgetary funds for agriculture, while the Republic of Serbia allocate much less funds, surely, in a relative sense. For example, the agrarian budget of the Republic of Serbia in 2014 was about $4.1 \%$ of the national budget. In this ignores the fact that these two ciphers cannot be compared. There are numerous reasons for that.

The common agricultural policy is financed from the central EU budget, which forms from the following sources (Bureau and Mahe, 2008):

1. Agricultural duties, which make around $3 \%$ of total EU budget,

2. Fixed share of GDP of EU member countries is the main source of financing and makes $45 \%$ of total budget,

3. Customs duties participate with $15 \%$ in creating the budget,

4. Value added tax makes $37 \%$ of the budget.

The common agrarian policy of the European Union is grouped in two columns, i.e. in Column I and Column II. This way of expressing the budget expenditures has become popular after the reforms in 2000. When the agrarian budget expenditures express in this way, the column I represents expenditures meant for the market support (Analysis of the 2003 CAP reform, OECD 2004):

$\checkmark$ Support measures to some products by intervention buying or subsidies for private storage,

$\checkmark$ Models of support by purchasing for emergencies and the support to manufacturer groups,

$\checkmark$ Direct payments, often through the production quota system or reference yields or areas due to the budget expenditure restrictions,

$\checkmark$ Measures for the regulation of production by production quotas, maximum storage and obligatorily leaving the specific land uncultivated,

$\checkmark$ Other measures related to environmental issues and conditions for keeping animals.

If it is about the column II, the measures are regulated by the regulations for rural development and comprise (Rikalović and Jovanović-Gavrilović, 2008):

$\checkmark$ Compensation for cultivating less favourable areas and areas endangered by natural disasters,

$\checkmark$ Agro-protective measures,

$\checkmark$ Support to forestry,

$\checkmark$ Subsidies for investments on farms, modernization and diversification,

$\checkmark$ Subsidies for marketing and processing of agricultural products,

EP 2017 (64) 1 (339-358) 
$\checkmark$ Support for early retirement, as well as the support for young farmers,

$\checkmark$ Training programs,

$\checkmark$ Programs to improve water management, land planning and improvement,

$\checkmark$ Support to rural tourism development and activities from the handicrafts category,

$\checkmark$ Other measures of support to rural development in accordance to the clause 33 .

Table 1. Distribution of direct payments from the European Union and the national budgets of the EU new members (in \%)

\begin{tabular}{|c|c|c|c|}
\hline Year & $\begin{array}{c}\text { From the European } \\
\text { Union budget }\end{array}$ & $\begin{array}{c}\text { From the national } \\
\text { budget }\end{array}$ & Total \\
\hline 2004 & 25 & 30 & 55 \\
\hline 2005 & 30 & 30 & 60 \\
\hline 2006 & 35 & 30 & 65 \\
\hline 2007 & 40 & 30 & 70 \\
\hline 2008 & 50 & 30 & 80 \\
\hline 2009 & 60 & 30 & 90 \\
\hline 2010 & 70 & 30 & 100 \\
\hline 2011 & 80 & 20 & 100 \\
\hline 2012 & 90 & 10 & 100 \\
\hline 2013 & 100 & 0 & \\
\hline
\end{tabular}

Source: Analysins of the 2003 CAP reform, OECD 2004.

According to the same source (Rikalović and Jovanović-Gavrilović, 2008), the traditional approach to common policy of agriculture funding in modern life conditions, when more attention pays to the protection of human health and environment, suffers the same critics and by this experiences some changes. The goals of future EU agrarian policy are directed to:

$\checkmark$ Improvement of competitiveness - transfer of knowledge, innovation, risk management, cooperation in production chain, processing and sale of food,

$\checkmark$ Improvement of sustainability -green payments, cross-compliance, resource efficiency, research,

$\checkmark$ Higher efficiency - redistribution of funds, more precise placement of funds, simplification of procedures.

As for other policies within the European Union, in the same way the common agricultural policy is anticipated the maximum budget within 7-year-lasting cycle (2014-2020). New Multiannual EU financial framework for the period 2014-2020 anticipates the total budget for the realisation of common agrarian policy in amount of 408.3 milliard euros, or $38 \%$ of the total EU budget, which points out to significant decrease of share in the total EU budget in past 30 years, when the share for common agricultural policy was amounted up to $75 \%$ of the total budget (Rikalović and Jovanović-Gavrilović, 2008). 
Chart 1. Distribution of direct payments from the European Union and the national budgets of the European Union new members (in \%)

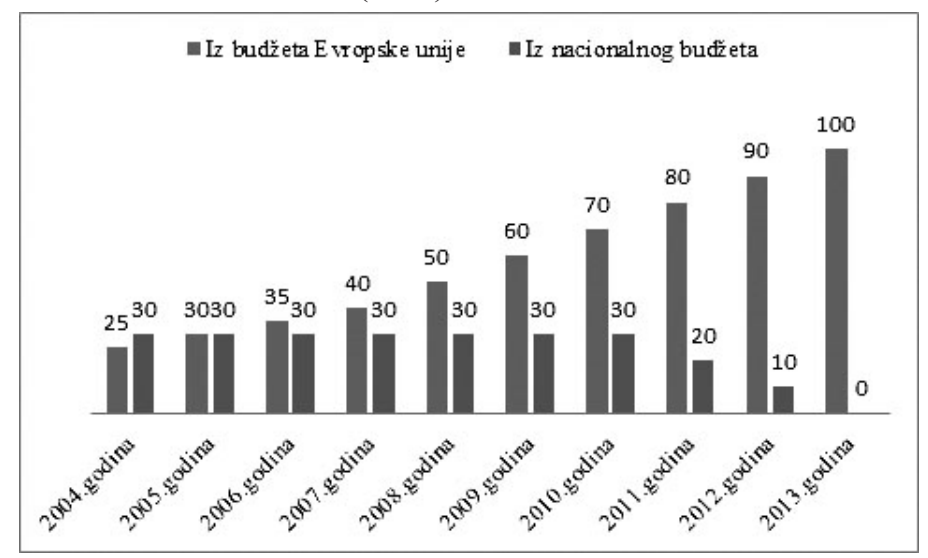

Source: Authors

\section{Policy of financing the agrarian production in Serbia}

Agricultural production in Serbia, as an important economic branch and with unused potential, should be a significant moment of political and economic recognition, aiming to solve problems which follow the production. Insufficiently used capacities are the consequence of poor engagement of farmers, insufficient care and support for their position in economic processes. Technologically and technically poorly equipped are not capable to intensify their results in quantitative sense, as well as to manufacture larger amounts of healthy food without problem to sell these products. All of these point out to lack of financial resources, as well as a better regulatory framework of agricultural production.

Inadequate agricultural policy results in disintegration of rural population in small and big, on manufacturers who are engaged in the specific branches of agricultural production, enhancing migrations in rural-urban relation, on negative trends in foreign trade exchange of agro-food products etc. (Popović, Simonović, Živković, 2004).

On the way of redefining policy are restrictions which agriculture/state/policy meets, personified in insufficient financial resources for the support to agriculture and rural development, inadequate analytical framework for creating the efficient policy, absence of specialised institutions/state authorities for providing support to agriculture, in heritage of the previous socio-political arrangement, inertness of participants. However, the main activities of the state are well-known and can be classified in three basic: legislative, financial and institutional (Popović, Simonović, Živković, 2004).

From the economic point of view, the agricultural production should get the legislative and institutional framework, financial support regardless to which direction the state will take in future. Approaching to EU is surely set as a goal, as well as a task of all relations harmonization, and this should be done, without doubt, as soon as possible and in the painless way. Many of the advantages from setting up the EU regulatory framework should be used 
regardless to the state foreign-policy priorities.

Stable policy in the field of agriculture implies the application of the same (or about the same) set of selected measures of agrarian-rural policy in a multi-year period. This set has to be personified in certain kind of a strategic document and verified in the Republic of Serbia National Assembly, as a legislative body. This verification provides an immutability seal, since every eventual change will require a parliamentary debate. In practice, this means proficiency in defined and adopted rules of the game, in mid-term period, by all participants in agro-business, but also the potential new participants. It is especially significant for building a stable and stimulating environment for business of the local entities of agribusiness, but also attracting foreign investors for this sector (Popović, Simonović, Živković, 2004).

\section{Financial support to agriculture}

Financial support to farmers can go in several directions. Surely more favourable credits would be one of the forms for finding more favourable financial resources, which can be very important in satisfying farmers' needs, by their sources of financing. The second, very important segment is tax policy for farmers and their products, pursued by the government. We have already mentioned subsidies on insurance premiums, which can help and provide stimulus for agricultural production. Accordingly, the basic modalities for finding financial resources for the development of agricultural production are:

- Favourable credits (lower interest rates, easier approval of credits and the adequacy of a size and purpose of funds),

- Tax system (real rates and base, as well as the introduction of incentives),

- Subsidies (prices of products, insurance premiums and others).

Taking into consideration the great significance of agricultural production in Serbia, banks offer credits meant for farmers, working capital and the purchase of fixed assets. There are also credits for the registration of agricultural holdings for which the state subsidizes an interest, and are meant for the purchase of raw materials and other working assets. The credits are short-term with a maturity of 3-12 months. An interest rate related to these types of credits is significantly lower than the one related to other credits. Long-term subsidized credits, in cooperation with the Ministry of Agriculture, Forestry and Water Management, are meant for investing in fixed capital in agriculture - purchase of agricultural machinery and equipment, purchasing a foundation stock, investing in facilities in agriculture, the irrigation system and other fixed assets. Repayment of these credits is planned in quarterly, semi-annual and annual annuities, with the period of the beginning from 12 to 36 months, depending on the credit purpose (http://www.tvojnovac.nbs.rs/edukacija/latinica/20/krediti/ poljoprivredni_krediti.html).

In this manuscript, we give the examples of business banks which approve agricultural credits in domestic market. The basic condition, which every user of agricultural credit has to fulfil, is that an agricultural holding is registered in the Register of Agricultural Holdings, within the applicable regulations related to registering and the registration renewal, that they are active 
and have opened a purposeful bank account. What is important to mention is that, besides an interest rate paid by a credit user, he additionally pays the costs of collateral subscriptionor mortgage, valuations, various certificates, permissions, statements, cadastre costs and other documentation. Finally, he pays additionally the costs of deleting of bank right enrolment, as well as the insurance costs, processing of credit request, certificated of a credit bureau. All of these items burden substantially an applicant, in this case - a farmer.

BancaIntesa is one of the leading banks regarding a number of credit lines for agriculture, by an amount of approved funds and a number of approved credits. It offers more products on the market and some of them are (http://www.bancaintesa.rs/intesafarmer-krediti/intesafarmerkrediti.116.html):

Farmer turnover in RSD.This type of credit can be in RSD or indexed in euros. Repayment term of this credit is 24 months, while the grace period is up to 12 months. It repays in equal monthly, semi-annual and annual annuities or on maturity date. The purpose of this credit is to invest in production materials, fodder, medicines, other veterinarian costs, cattle intended for fattening, other fatteningcosts, etc.

Farmer invest in RSD. Credit can be approved in RSD or indexed in euros. Credit repayment term is up to 60 months for credits in RSD or up to 120 months for credits indexed in euros. The grace period for this type of credit is up to 24 months. The repayment is done in equal monthly, quarterly, semi-annual annuities. These credits are meant for the purchase of machinery, equipment, land, facilities for agricultural production, investments in greenhouses, glasshouses, permanent cropping, foundation stock, the irrigation system etc.

Credit frameworks for purchasing agricultural land.The credit is indexed in euros. The repayment term of this form of credit is 120 months, while the grace period is 12 months. It repays in equal monthly, quarterly, semi-annual or annual annuities.

Credits in cooperation with the Guarantee Fund of the Autonomous Province of Vojvodina. According to the legitimate agreement between the Guarantee Fund of AP Vojvodina and BancaIntesa, the offer of the bank is meant for financing agricultural holdings, extended with credits for the purchase of agricultural machinery and equipment, as well as the credits for financing the purchase of agricultural land. These credits are meant exclusively for purchasing combines, tractors and other self-propelled agricultural machines, agricultural working machines, as well as the purchase of equipment. The amount of credit ranges from 5,000 to 100,000 euros in RSD equivalent by the official exchange rate of the National Bank of Serbia on the day of credit disbursement. The repayment term of this type of credit is 7 years in equal semi-annual annuities.

Agro-protect - credit with insurance. This is a unique type of credit which ensures free insurance of crops from natural disasters (maize, wheat, sunflower, soy bean, barley and sugar beet). It is meant for all registered holdings in Vojvodina which are engaged in crop farming. The amount of the credit ranges from 1,000 to 100,000 euros in RSD equivalent; the repayment term is up to 12 months in monthly, quarterly or semi-annual annuities or on maturity date. 
The Commercial Bank(http://www.kombank.com/poljoprivreda) is the only one state-owned and it approves credits to farmers in RSD, without a currency clause, with the state subsidy, Ministry of Agriculture, Forestry and Water Management. The purpose of this credit is livestock breeding development, the development of crop farming, fruit growing, vegetable growing and flower-growing, investments in a new agricultural machinery and equipment, except attested used truck for transport of built bee hives, when the allowed purchase of used vehicle is 500,000 RSD of individual value. Nominal interest rate is from $4 \%$ fixed for the livestock breeding development, to $6 \%$ fixed for other purposes, in accordance with the Regulations. The credit repayment term is 36 months from a date of credit permission, with a grace period up to 12 months. The credit repayment is in annuities: monthly, quarterly or semi-annual and one time after 12 months. Maximum amount of the credit is 5 million RSD, while the costs of credit processing are $1.5 \%$, one time and in advance.

According to the support program to agriculture and rural development, adopted in 2016 (APV, 69/2016), there are plenty of novelties. In the previous year, subsidies were approved for:

$\checkmark \quad$ Purchasing the irrigation equipment,

$\checkmark \quad$ Anti-hail system,

$\checkmark \quad$ In the production of green houses and glass houses,

$\checkmark \quad$ In constructing and equipping the facilities for storing fruits and vegetables,

$\checkmark \quad$ Livestock production.

All these positions are increased by the support program for the year 2017, for example: irrigation for $35 \%$, anti-hail nets for $20 \%$, stimulating production in glass houses for around $33 \%$, for warehouses for $250 \%$, for livestock production $60 \%$, and the highest increase is for the organic production $10000 \%$ in regard to the year 2016 .

Besides the increase of budgetary financing for some positions in agricultural production, in this year are anticipated also new items such as:

$\checkmark \quad$ Non-repayable fundsfor purchasing machines for agricultural production (tractors, combines and others),

$\checkmark \quad$ Star up funds for the youth who decide to start production in rural areas.

Support to young people in rural areas by start-up funds in amount of 100 million RSD is surely the measure for which many would be interested. The amount is up to $100 \%$ of total acceptable costs, minimum 500,000 RSD, maximum 2,500.000 per user (http://subvencije. rs/vesti/apv-usvojen-plan-bespovratna-sredstva-za-ratarske-traktore-kombajne-u-2017-oj/).

Obtained money young people cannot use to buy land, heads of cattle and seed. For example, young people who plan to invest in a glasshouse in over 500 meters above sea level can expect a refund up to $70 \%$. In that way, by planning a greenhouse construction on $20 \mathrm{a}$, which costs about 20,000 euros, an investor can expect the refund in amount of 14,000 euros. 
ProCredit bank pays special attention to agricultural credits. This bank offers the next forms of agricultural credits(https://www.procreditbank.rs/strana/2131):

$\checkmark$ Credits for the agricultural production improvement,

$\checkmark$ Subsidized loans, in cooperation with the Ministry of Agriculture,

$\checkmark$ Credits for the quality of life improvement,

$\checkmark$ Cash credits.

This bank, besides crediting, also cooperates with the manufacturers of agricultural machinery, and thereby facilitates a client to purchase the machinery.

OTP Bank is also one of the banks whichoffer favourable agricultural credits. One of the credit types for this purpose is fast credits for working capital. The basic characteristics of these credits are (https://www.otpbanka.rs/poljoprivreda/poljoprivreda_brzi_krediti_za obrtna_sredstva.php):

$\checkmark$ Favourable interest rate,

$\checkmark$ RSD credit-no currency risk,

$\checkmark$ Credit bureau report and a bill of exchangeare paid by a bank.

$\checkmark$ Flexible repayment: interest rate monthly or quarterly, quarterly or semi-annual,

$\checkmark$ Credit repayment within two days.

Table 2. Review of agricultural machinery suppliers

\begin{tabular}{|l|l|l|}
\hline \multicolumn{2}{|l|}{ Tractor } & Combines and working machines \\
\hline Case & Massey Ferguson & \\
Claas & Mahindra & Case \\
DeutzFahr & McCormick & Claas \\
Foton & MTZ Belarus & John Deere \\
Fendt & New Holland & SAMPO \\
Europard & Rakovica & FENDT \\
& Tafe & New Holland \\
IMT & UZM & Sistemzanavodnjavanje \\
Johan Deere & Zetor & Tifon \\
Kubota & YTO & \\
\hline
\end{tabular}

Source: The authors according to https:/www.procreditbank.rs/strana/3531/krediti-za-unapredenjepoljoprivredne-proizvodnje (02.01.2017).

The state provided subsidies in terms of finding the favourable financial resources in form of part of interest rate or insurance premium. The bank and insurance companies' representatives have assessed that this program will significantly contribute to the agricultural production improvement, in individual holdings, and the interest for this has been growing from year to year. The contracts are concluded with the following banks(http://subvencije.rs/krediti/7854/):

$>$ Commercial Bank

$>$ ProCredit Bank

> Credit Agricole Bank 
$>$ Hypo AlpeAdria Bank

$>$ BancaIntesa

$>$ Sberbank

$>$ AIK Bank

$>$ NLB Bank

$>$ Unicredit Bank

$>$ OTP Bank

On the other hand, the contracts were concluded also with insurance underwriters (http:// subvencije.rs/krediti/7854/):

$>$ Dunav insurance,

$>$ Delta Generali insurance,

$>$ DDOR Novi Sad,

$>$ Triglav insurance,

$>$ Globos insurance.

\section{Various programs of the state support to agriculture}

Subsidies in the field of agriculture comprise the set of different measures which is characterized by an unequalised form of internal support. Measures of the national program for agriculture and rural development of the Republic of Serbia for the period 2014-2020 (http://www.poljosfera.rs/agrosfera/agro-teme/ostalo/nacionalni-program-za-poljoprivredui-ruralni-razvoj-republike-srbije/):

$\checkmark$ Investments in physical assets of agricultural holdings,

$\checkmark$ Investments in processing and marketing of agricultural products and fishery products,

$\checkmark$ Diversification of rural economy,

$\checkmark$ Rural infrastructure,

$\checkmark$ Creation, transfer of knowledge and the extension development,

$\checkmark$ Measures and preservation of the environment,

$\checkmark$ Development of forestry in rural areas,

$\checkmark$ Preparation of the local strategies of rural development - partnership for the territorial rural development - LEADER approach.

The national program for agricultural and rural development of the Republic of Serbia 20142010 is an instrument for financial support in the field of rural development. It defines measures for the rural development support in accordance with the valid national legal decisions, as well as the criteria and financial framework of support. IPARD program of the Republic of Serbia means an instrument for pre-accession support in the field of rural development for the program period 2014-2020 -reaching the European standard and raising competitiveness.

The IPARD program is an instrument for the pre-accession support in the field of rural development for the period 2014-2020. This document is approved by the EU Directorate- 
General for Agriculture and Rural Development.It defines measures for the rural development support in compliance with the current European Union regulations. Measures of IPARD program are as follows (http:/www.poljosfera.rs/agrosfera/agro-teme/ostalo/nacionalniprogram-za-poljoprivredu-i-ruralni-razvoj-republike-srbije/):

The first phase is:

$\checkmark \quad$ Investments in physical property of agricultural holdings,

$\checkmark$ Investments in processing and marketing of agricultural products and fishery products,

$\checkmark$ Diversification of agricultural holdings and business development,

$\checkmark$ Technical support.

The second phase is:

$\checkmark$ Implementation of the local strategies of rural development,

$\checkmark$ Agro-ecological-climate measures (actions) and the organic production measures.

Table 3. Analysis of budget according to individual measures in the period 2014-2015 (in 000 euro)

\begin{tabular}{|c|l|l|l|l|l|l|l|}
\hline Measure & 2015 & 2016 & 2017 & 2018 & 2019 & 2020 & $\begin{array}{c}2014- \\
2020\end{array}$ \\
\hline $\begin{array}{c}\text { Investments in } \\
\text { physical property } \\
\text { in agricultural } \\
\text { holding }\end{array}$ & 7,535 & 9,900 & 10,622 & 11,199 & 17,002 & 19,780 & 76,040 \\
\hline $\begin{array}{c}\text { Investments } \\
\text { in physical } \\
\text { property related } \\
\text { to the processing } \\
\text { and sale of } \\
\text { agricultural } \\
\text { products and } \\
\text { fishery products }\end{array}$ & 6,164 & 8,099 & 8,690 & 9,162 & 13,910 & 16,182 & 62,210 \\
\hline $\begin{array}{c}\text { Aggro-ecological } \\
\text { climate measures } \\
\text { and the organic } \\
\text { production } \\
\text { measures }\end{array}$ & - & - & 2,187 & 2,187 & 2,187 & 2,187 & 8,750 \\
\hline $\begin{array}{c}\text { Implementation } \\
\text { of the local } \\
\text { developmental } \\
\text { strategies - } \\
\text { LEADER } \\
\text { approach }\end{array}$ & - & 500 & 1,000 & 1,900 & 1,850 & 5,250 \\
\hline
\end{tabular}




\begin{tabular}{|c|c|c|c|c|c|c|c|}
\hline $\begin{array}{c}\text { Diversification } \\
\text { of agricultural } \\
\text { holdings }\end{array}$ & 1,000 & 1,500 & 2,000 & 5,000 & 4,000 & 4,000 & 17,500 \\
\hline Technical support & 300 & 500 & 1,000 & 1,450 & 1,000 & 1,000 & 5,250 \\
\hline TOTAL & 15,000 & 20,000 & 25,000 & 30,000 & 40,000 & 45,000 & 175,000 \\
\hline
\end{tabular}

Source: http://www.poljosfera.rs/agrosfera/agro-teme/ostalo/nacionalni-program-za-poljoprivredu-iruralni-razvoj-republike-srbijel, (15.01.2017).

In high developed countries, the government intervenes in four directions (Pejanović, Tica, Tomašević, 2003):

- Determines the appropriate policy of agrarian product prices,

- Determines the measures of inputs subsidizing for different types of costs,

- Determines the adequate models of financing the agrarian production and stocks,

- Subsidizing export of agrarian products.

The support to agriculture and rural development, provided by a Decree and Law, has amounted in 2014 around 34.5 milliards RSD. In comparison with the previous year, this amount is for 7.6 milliard RSD higher, which points out to a fact that funds in 2014 spent on financing incentives in agriculture and rural development were increased for $28 \%$ (Official Gazette of the Republic of Serbia, no. 8/2014, 30/2014, 116/2014, 128/2014, 137/2014 and 144/2014).

Besides the IPARD program, big incentives for agricultural development are provided also by the relevant ministry of the Republic of Serbia. That is to say, a prevailing part of a relevant ministry's budget is in function of the current measures of agrarian policy realisation. Premiums for milk, subsidies for industrial plants, recourses for inputs and the export stimulation represent basic forms of the current incentives of agricultural production in our country. Basic instrument for direction of the entrepreneurial farming development are subsidies meant for the increase of investments in the agrarian sector. Besides credits, they realise by non-repayable funds and input subsidies. Reform of the agrarian policy implies redirecting the current subsidies, which are mainly defined to so called developmental subsidies, so the most important position in the agriculture financing program in 2017 , is exactly the investment in new capacities, the development-oriented policy.

\section{Conclusion}

As a subject of research in this manuscript is an issue of state impact to the production of sufficient amount of food and these products quality, while the aim of the policy is as higher as possible standard of their population. A significant role in achieving set goals plays the state interventionism and a systemic effort to solve the issue of hunger and health of population by the state impact.

Economically more developed countries surely thrive, while they easily set goals by their 
policy and financial impact. Through subsidies, tax reliefs, law regulations and in other ways is realized a substantial influence to agricultural production. However, in those countries don't insist on liberalisation at all costs, and a good agricultural policy is one that provides an abundance of healthy food. In order to make success, there are very important sources of funding for subsidizing the agricultural production. The state impact by budgetary financing of the agricultural production sector provides sufficient quantity of food for domestic market, and besides there achieves a significant export of these products. Taking into consideration the potentialand strength of domestic sector, we can conclude that the state encouragement would be multi-useful, as for manufacturers and consumers, as well as for the state, through a direct increase in export and more cautious tax policy, and indirectlyhigher budget revenues in long-term period.

Taking into consideration a level and capacity of other countries, we can tell that Serbia has a great potential for agricultural production, not only in quantitative sense, but also aiming to manufacture healthy food. Arable land area we dispose with, as well as its quality, gives us the right to assess. Geographic position of the state goes in favour of the fact that we are very close to markets, which are great in demand, but also to those very demanding in respect of products quality. Serbia has good economic relation with the Russian Federation and this trade exchange grows in respect of our agricultural products export, while the EU becomes more and more demanding regarding healthy food, where is still difficult to sell goods.

What lacks is, first of all, a low level of technical and technological competence of domestic manufacturers. Machinery is obsolete, and small percentage of arable land cultivates, along with the use of older processing technology and production. In this manuscript is given the review of the EU subsidy policies in agriculture and the conclusion is that without interventionism, the domestic market won't make more visible progress without the state impact.

The current policy of funding and the state impact on agricultural production has been characterized by direct investments per hectare of arable land, which has made possible some frauds in the process of approving and spending these funds, while the goal that was set hasn't been completely realised. Priority was given to plant production, while livestock breeding was completely neglected in this structure of funding. We know that livestock fundin Serbia has been almost destroyed, and we have good conditions for this production development. Finally can be established a fact that the level of funding for plant production was insufficient in previous years as well. The fact that the current government pays more attention to this issue, and that financing increases from year to year proves this observation. One of the important moments of budgetary financing is surely their structure, and not only purpose. From this year, the funds have been directed more to investments in agriculture, young people are given the chance to stay in the country and get involved in this activity. Perhaps an even greater stimulus for young people would be to find a way to come easier to arable land through some kind of cooperation with the state, in order to smooth the way for young people, and at the same time use the potential and increase the percentage of arable utilised land. 
If we observe the domestic economy, trends we have accepted and which have resulted in the increase in GDP and increase of export, which has been mainly the result of foreign investors, and however has provided the indices of growth and development, the question of agricultural production has been arisen. The state impact is necessary, financial resources by which the state can help in agricultural production development and their spending policy should be in the context of a national interest. Production of a greater amount of food with an adequate use and respect of all agro-measures, but the production which can be competitive, along with the use of modern techniques and technology, the application of adequate tax and other measures. The second direction is healthy food production, which also requires the state interventionism, but not only in financial resources, but probably more in creating a regulatory framework that will help in overcoming barriers for selling these products on foreign markets.

Even if the forthcoming process of euro-integrations of our country takes into consideration, but also more important - a great need of agricultural sector, on the other hand, the significant change in the agrarian budget structure is inevitable. Reconsidering the state support policy to agriculture should be in direction of larger allocation of funds meant for livestock production and underrepresented branches of plant production, but also for rural development, and not only through the investment measures, but also the measures which aim generally to improve life conditions in village.

\section{Literature:}

1. Birovljev, J., Glamočanin, B., (2011). Poljoprivreda Srbije i materijalno finansijski podsticaji u odnosu na kretanje u Evropskoj uniji, DAES-Društvo agrarnih ekonomisa Srbije, Univerzitet u Novom Sadu, Ekonomski fakultet, Novi Sad.

2. Birovljev J., Tomić R.,(1996). Menadžment u poljoprivredi, Ekonomski fakultet Subotica.

3. Birovljev, J., Vojinović, Ž., Balaban, M., (2015), Potentional of agricultural production and its impact on insurance premiums, Economics of Agriculture, Naučno društvo agrarnih ekonomista Balkana, Institut za ekonomiku poljoprivrede, Akademija ekonomskih nauku Bukurešt, Year 62, No. 3 (575-898), (ISSN- 0352-3462), Belgrade, pp.705-723.

4. Bogdanov, N., (2007), Mala ruralna domaćinstva u Srbiji i ruralna nepoljoprivredna ekonomija, UNDP, Beograd, ISBN 978867728075 8, pp.49-53.

5. Bogdanov, N., Babović, M.,(2012), Radna snaga i diverzifikacija prihoda na poljoprivrednim gazdinstvima u Srbiji - stanje i izazovi za politiku ruralnog razvoja, Zbornik radova: Primena podataka Popisa poljoprivrede 2012. u analizi stanja poljoprivrede i u planiranju agrarne politike u Republici Srbiji, Republički zavod za statistiku, Subotica, ISBN978-8686-6161- 115-5, 2014, p. 262.

6. Brkanić, M.,(1996), Priručnik za praksu u osiguranju i reosiguranju, Novi Sad, 1996, p.247.

7. Bureau, JC., Mahe, LP.,(2008). CAP reform beyond 2013: An idea for a longer view, Notre Europe, Paris. 
8. Maliva, R.G., Missimer, Th.M. (2012). Air Lands Water Evaluation and Management, New York, Springer, USA.

9. Mihailović, B., Cvijanović, D., Hamović, V.(2009).Analiza investicione i izvozne aktivnosti poljoprivrede Srbije, Ekonomika poljoprivrede, br./ $\mathrm{N}^{\mathrm{o}} 1$ (1-138), Naučno društvo agrarnih ekonomista Balkana, Institut za ekonomiku poljoprivrede, Akademija ekonomskih nauku Bukurešt, Beograd, p. 17.

10. Pejanović, R., Tica, N., Tomašević, D.,(2003). Faktori konkurentnosti agroprivrede u procesu tranzicije u publikaciji Kompatibilnost agrarne politike SCG i zajedničke agrarne politike EU, Institut za ekonomiku poljoprivrede Beograd, Beograd.

11. Popović, V., Simonović, V., Živković, V.(2004). Performanse agrarnog sektora u tranziciji, Naučni skup sa međunarodnim učešćem Poljoprivreda u tranziciji - komparativna iskustva i perspektive, Beograd, 15-16. oktobar, Institut za ekonomiku poljoprivrede, Beograd i Ekonomika poljoprivrede. Tematski zbornik, urednici: dr Rajko Bukvić, prof. dr Milan Milanović, Institut za ekonomiku poljoprivrede, Neograd.

12. Rikalović, G., Jovanović-Gavrilović, B.(2008). Ekonomska politika i privredni razvoj, Ekonomski fakultet Beograd, Beograd.

13. Stanković, M.,(2012),Agrarna politika Srbije i zajednička poljoprivredna politika, Škola biznisa, Broj 3/2012, UDC 338.43.02(497.11), str. 65.

14. Službeni glasnik Republike Srbije, Republika Srbija,(2014), broj 8/2014, 30/2014, 116/2014, 128/2014, 137/2014 и 144/2014, Beograd.

15. Tsakiris, G., Vangelis, H. (2005): Establishing a Drought Index Incorporating, Evapotranspiration, European Water, 9/10, pp. 3-11, E. W. Publications, Athens, Greece.

16. Zakić, Z., Stojanović, Ž.,(2008). Ekonomika agrara, Centar za izdavačku delatnost Ekonomskog fakulteta, Beograd.

17. Analysins of the 2003 CAP reform, OECD 2004, available at:https://www.ers.usda. gov/webdocs/publications/wrs0407/49119 wrs0407.pdf,(12.01.2017).

18. Banka Inteza, available at: http://www.bancaintesa.rs/intesafarmer-krediti/ intesafarmer-krediti.116.html, (22.01.2017).

19. http://euinfo.rs/files/Publikacije-srp/31_Poljopricreda i EU.pdf,10.10.2016

20. Narodna banka Srbije, available at : http://www.tvojnovac.nbs.rs/edukacija/ latinica/20/krediti/poljoprivredni_krediti.html, 19.01.2017).

21. Komercijalna banka Beograd, available at: http://www.kombank.com/ poljoprivreda, (26.01.2017).

22. OTP banka Srbija, available at:https:/www.otpbanka.rs/poljoprivreda/ poljoprivreda brzi krediti za obrtna sredstva.php, (27.01.2017).

23. http://www.poljosfera.rs/agrosfera/agro-teme/ostalo/nacionalni-program-zapoljoprivredu-i-ruralni-razvoj-republike-srbije/, (01.02.2017).

24. http://www.poljosfera.rs/agrosfera/agro-teme/ostalo/nacionalni-program-zapoljoprivredu-i-ruralni-razvoj-republike-srbije/, (01.02.2017). 
25. Procredit banka Srbije, available at:https://www.procreditbank.rs/strana/2131, https://www.procreditbank.rs/strana/3531/krediti-za-unapredenje-poljoprivredneproizvodnje, (23.01.2017).

26. Republika Srbija-subvencije poljoprivrednoj proizvodnji, available at:

http://subvencije.rs/vesti/apv-usvojen-plan-bespovratna-sredstva-za-ratarske-traktorekombajne-u-2017-oj/, http://subvencije.rs/krediti/7854/, 04.02.2017).

\title{
PROGRAM DRŽAVNE PODRŠKE U KREDITIRANJU POLJOPRIVREDE
}

\section{Željko Vojinović4, Vera Zelenovićs, Drago Cvijanovićc}

\begin{abstract}
Apstrakt
Jedna od najbitnijih privrednih delatnosti u Srbiji jeste poljoprivreda, potencijal koji za državu, koja je na putu da postane član Evropske unije, predstavlja oslonac privrednog rasta i razvoja. Integrisanje sa EU predstavlja i zadatak da se uspostavi takav model i okvir odnosa države prema poljoprivredi u cilju lakše harmonizacije nacionalne politike sa politikom EU. U današnje vreme kada raste svest o važnosti ishrane a samim tim i značaju obradivog zemljišta neophodno je posebnu pažnju posvetiti problemu nedostatka novčanih sredstava u okviru agrarne proizvodnje. Rešenje problema tehničko-tehnoloških procesa u proizvodnji prehrambenih proizvoda, posebno zdrave hrane, može da se potraži u merama unapređenja i povećanja proizvodnje kroz različite pristupe stimulisanja i subvencionisanja poljoprivrednih proizvođača. To je svakako $u$ interesu države pa je iz tog razloga potrebno posvetiti posebnu pažnju budžetu i načinu finansiranja i drugih mera u pravcu stimulisanja svih učesnika na tržištu koji učestvuju u poljoprivrednoj proizvodnji.
\end{abstract}

Ključne reči: poljoprivredna proizvodnja, politika finansiranja, kreditiranje, razvoj, harmonizacija.

4 Docent, $\mathrm{dr}$ ŽeljkoVojinović, Univerzitet u NovomSadu, Ekonomskifakultet Subotica,Segedinski put br. 9-11, 24000 Subotica, Srbija, Telefon +381 24628 030, E-mail: zeljko.vojinovic@ef.uns.ac.rs,

5 Profesor, dr Vera Zelenović, Univerzitet u NovomSadu, Ekonomskifakultet Subotica,Segedinski put br. 9-11, 24000 Subotica, Srbija, Telefon +381 24628 164, E-mail:vera.zelenovic@ef.uns.ac.rs.

6 Profesor, dr Drago Cvijanović, Univerzitet u Kragujevcu, Fakultet za hotelijerstvo i turizam u Vrnjačkoj Banji, Vojvođanska 5A, 36210 Vrnjačka Banja, Srbija, Telefon: +381 63295 111, E-mail: $\underline{\text { dvcmmv@gmil.com }}$ 
ECONOMICS OF

AGRICULTURE

\section{CONTENT}

1. Željko Anđelković, Aleksandra Dragin, Sanja Božić, Kristina Košić

EMOTIONAL EXHAUSTION AND JOB SATISFACTION OF TOUR GUIDES IN RURAL AREAS . . . . . . . . . . . . . . 11

2. Sanja Đukić, Danica Glavaš-Trbić, Nikola Banjac

MANAGEMENT PROBLEMS OF RURAL DEVELOPMENT IN FRUŠKA GORA . . . . . . . . . . . . . . . . . . . . 27

3. Ivana Ilić, Bojan Krstić, Sonja Jovanović

ENVIRONMENTAL PERFORMANCES OF AGRICULTURE IN THE EUROPEAN UNION COUNTRIES . . . . . . . . . . . . . 41

4. Nataša Kljajić, Jonel Subić, Zorica Sredojević

PROFITABILITY OF RASPBERRY PRODUCTION

ON HOLDINGS IN THE TERRITORY OF ARILJE. . . . . . . . . . . 57

5. Aleksandar Maksimović, Zoran Grgić, Ferhat Ćejvanović

MULTI-ATTRIBUTE ANALYSIS OF ORCHARD ACCORDING

TO THE INTEGRATED PRODUCTION CONCEPT . . . . . . . . . . 69

6. Ozrislava Milinković, Branislav Jakić, Slobodan Vuksanović,

Dragana Macura, Milica Šelmić

MULTI- CRITERIA DECISION BASED APPROACH

TO SELECTING THE TYPE OF INDUSTRIAL HALLS

USED IN FOOD INDUSTRY $\ldots \ldots \ldots \ldots$. . . . . . . . . . 81

7. Gordana Nikić, Ljubiša Stamatović, Azra Sućeska

EMOTIONAL COMPETENCIES AND PERSONALITY

TRAITS OF MANAGERS IN MODERN AGROBUSINESS. . . . . . . .97

8. Vladimir Obradović, Nemanja Karapavlović

FINANCIAL REPORTING OF COMPREHENSIVE INCOME

IN THE FOOD AND BEVERAGE SECTOR

IN THE REPUBLIC OF SERBIA . . . . . . . . . . . . . . 113 
9. Aleksandar Ostojić, Nebojša Savić, Željko Vaško

CONSUMER ATTITUDES

ON BUYING FISH IN BANJA LUKA . . . . . . . . . . . . . . . 129

10. Radivoj Prodanović, Boris Kuzman, David Jovović, Lazar Ozegović

MARKET AND TRADE OF ORGANIC FRUITS IN SERBIA $\ldots . . .141$

11. Predrag Vukadinović, Aleksandar Damnjanović, Ljiljana Dimitrijević

ANALYSIS OF THE SALES AND INCOMES BETWEEN

DIFFERENT CATEGORIES OF AGRICULTURAL PRODUCTS . . . 157

12. Jugoslav Aničić, Svetlana Vukotić, Goran Maksimović

THE POSSIBILITIES AND LIMITATIONS

OF ENTREPRENEURSHIP DEVELOPMENT

IN AGRICULTURE IN SERBIA . . . . . . . . . . . . . . 171

13. Željko Bjelajac, Marijana Dukić - Mijatović, Joko Dragojlović

FOOD SAFETY AS ONE OF THE MAIN SAFETY $P$

REOCCUPATIONS OF A MODERN MAN . . . . . . . . . . . . . 191

14. Milan Bradić, Ljiljana Kosar, Lukrecija Djeri, Svetlana Vukosav, Vuk Garača

ECO-LABELLING OF ACCOMMODATION FACILITIES

AND ITS PERCEPTION BY RURAL TOURISTS:

CASE STUDY OF VOJVODINA . . . . . . . . . . . . . . 205

15. Vaso Jegdić, Iva Škrbić, Srđan Milošević

MODELS OF ENTREPRENURSHIP DEVELOPMENT

IN RURAL TOURISM DESTINATIONS IN VOJVODINA . . . . . . . 221

16. Duško Kuzović

MUSEUM OF VERNACULAR ARCHITECTURE OF WESTERN SERBIA

- Representative curtilages of the area surrounding middle

course of the river Drina and Podgorina . . . . . . . . . . . 239

17. Branko Mihailović, Zoran Simonović, Nikola Ćurčić

AGRICULTURAL RESOURCES AND DEVELOPMENT

PRIORITIES OF THE MUNICIPALITY OF STARA PAZOVA. . . . . 259

18. Radmilo Nikolić, Aleksandra Fedajev, Vidoje Stefanović, Silvana Ilić

THE AGRICULTURE SECTOR IN WESTERN BALKANS

- SOME CHARACTERISTICS OF DEVELOPMENT. . . . . . . . . . 275

19. Vladimir Njegomir, Rajko Tepavac, Nenad Ivanišević

ALTERNATIVE SOURCES OF FINANCING

ENTREPRENEURIAL UNDERTAKINGS IN AGRICULTURE . . . 295

Economics of Agriculture, Year 64, No. 1 (1-404) 2017, Belgrade 
20. Daniela Nuševa, Kristina Mijić, Dejan Jakšić

THE PERFORMANCES OF COFFEE PROCESSORS

AND COFFEE MARKET IN THE REPUBLIC OF SERBIA . . . . . . 307

21. Svetlana Roljević Nikolić, Predrag Vuković, Biljana Grujić

MEASURES TO SUPPORT THE DEVELOPMENT OF ORGANIC

FARMING IN THE EU AND SERBIA . . . . . . . . . . . . 323

22. ŽeljkoVojinović, Vera Zelenović, DragoCvijanović

PROGRAM OF STATE SUPPORT

TO AGRICULTURAL CREDITING. . . . . . . . . . . . . . . . 339

23. Nikola Vuksanović, Dragan Tešanović, Bojana Kalenjuk,

Milijanko Portić, Marija Knežević

SOCIO-DEMOGRAPHIC CHARACTERISTICS

AS DETERMINANTS OF DIFFERENCES

IN PERCEPTION OF LOCAL GASTRONOMY . . . . . . . . . . . . 359 